MICHAL HOLUBČÍK

University of Zilina, Slovakia

'e-mail: martin.vantuch@fstroj.uniza.sk

\title{
ALTERNATIVE METHODS OF OBTAINING GEOTHERMAL HEAT FROM THE EARTH
}

\section{ALTERNATYWNE METODY POZYSKIWANIA CIEPŁA Z WNĘTRZA ZIEMI}

DOI: $10.30540 /$ sae-2018-019

\begin{abstract}
The paper describes the possibility of obtaining low-potential heat of the earth from deep borehole. It describes the possibilities of using a heat pump in combination with a heat pipe. The gravity heat pipe with the working substance represents an alternative and more efficient heat transfer technique from the vertical earth borehole. The article describes the possibilities and measurements of using this method on the primary side of the ground / water heat pump.
\end{abstract}

Keywords: geothermal energy, heat pumps

\section{Streszczenie}

Artykut przedstawia możliwości odzysku niskotemperaturowego ciepła z wnętrza ziemi przy użyciu pionowego wymiennika gruntowego. Opisuje on zastosowanie pompy ciepła wspótpracujacej z rura ciepła. Takie rozwiązanie w przypadku wymiennika pionowego stanowi interesujaca koncepcje. Prezentowany wymiennik ciepla $w$ takim przypadku cechuje się większa wydajnością. Praca przedstawia możliwości i wyniki pomiarów dla pierwotnej strony układu pompy ciepła.

Slowa kluczowe: energia geotermalna, pompy ciepła

\section{INTRODUCTION}

Development and introduction of new energy technology is very important for safeness delivery, tenability and competitiveness energy sectors. Research pertinent to energetics considerably contribute for energy effectiveness (e.g. in the engine of cars) and diversification of energy through piggybacking on revivable source of power. Balk renewable energy sources range from too low - potentially heat contained in the surface and those situated more deeply below neutral zone (10-20 $\mathrm{m}$ away from the levels of surface earth). Heat is possible to gain in several ways. One of them is the system of vertical heat exchangers (earth probes). The system with vertical heat- exchanger does not require big jerked - in - fillings and is independent from the intense solar radiation, which impinges topsides earth. Vertical heat - exchangers effectively work virtually in all the geological environments, besides soils with low thermic conductivity (for example they are in dry sand or dry gravel).
In the surrounding of $\mathrm{ZU}$ there are two boreholes of $150 \mathrm{~m}$ depths for retrieving low - potential heat on principle vertical exchangers through the medium: - forced circulation heat carrier substance (with brine circulation),

- circulation heat carrier substance (heat pipes technology) on thermosyphon principle.

\section{IMPLEMENTATION BOREHOLE FOR LOW-POTENCIAL HEAT TRANSPORT}

Laboratory results from measuring on simulation field prepared for laboratory measurement, provided information for the next progress realization in the real conditions.

Two boreholes of over 150 meters depth were drilled at distance approximately 25 meters apart to avoid mutual thermic influenced. By the realization propeller with forced circulation with brine media was treated the same way as is used to heat the pump type of ground-water. This means U-type pipe PE 
$100 \mathrm{RC}$ is embedded in the soil massif with special sensors temperature. Sensors were attached to the pipe axis grouting duct designated for supply of bentonite to the bottom of the borehole. Liquid bentonite is then filled to the free space and air bubbles in the borehole from the bottom up to the surface of the tubes are removed. Contact surface of the tubes will provide more efficient heat transfer to vertical heat exchangers. Temperature sensors were positioned to detect high temperatures accelerate changes in four different depth of the borehole and in the range 150, 100, 50 meters and $2 \mathrm{~m}$ close to the ground surface. The thermocouples type $\mathrm{K}(\mathrm{NiCr}-\mathrm{Ni})$ series TFAU were used. There being it is an thermocouple wires, it should provide safe berth of the measurement ends so as not to damage when the pipes set into the ground. For this reason, these thermocouples were attached to removal ribbons of short sections of pipe for injection, which is held in the middle of the piping system of PE $100 \mathrm{RC}$ geothermal probes.
Thermocouples are so protected in the pipe to collect heat. Heat pipe of the second hole is made in the same way, but on the surface of the borehole they will be equipped with specially designed heat exchanger for heat pipes of this type. Gravitational heat pipe working on the principle of phase transition working substance of $\mathrm{CO}_{2}$ will work under high pressure because at $0^{\circ} \mathrm{C}$ exists saturated vapor pressure of this substance around 35 bar. It is 5 times more than in ammonia $\mathrm{NH}_{3}(\mathrm{R} 717)$, which is also part of the experiment using heat pipe.

This method of obtaining low-potential heat by HP is a method in the research stage. It is therefore necessary to have a detailed overview of all the thermodynamic processes in its operation. Stainless steel heat exchanger for HP will be planted about 1.5 meters in the ground in sewage shaft on the concrete surface.

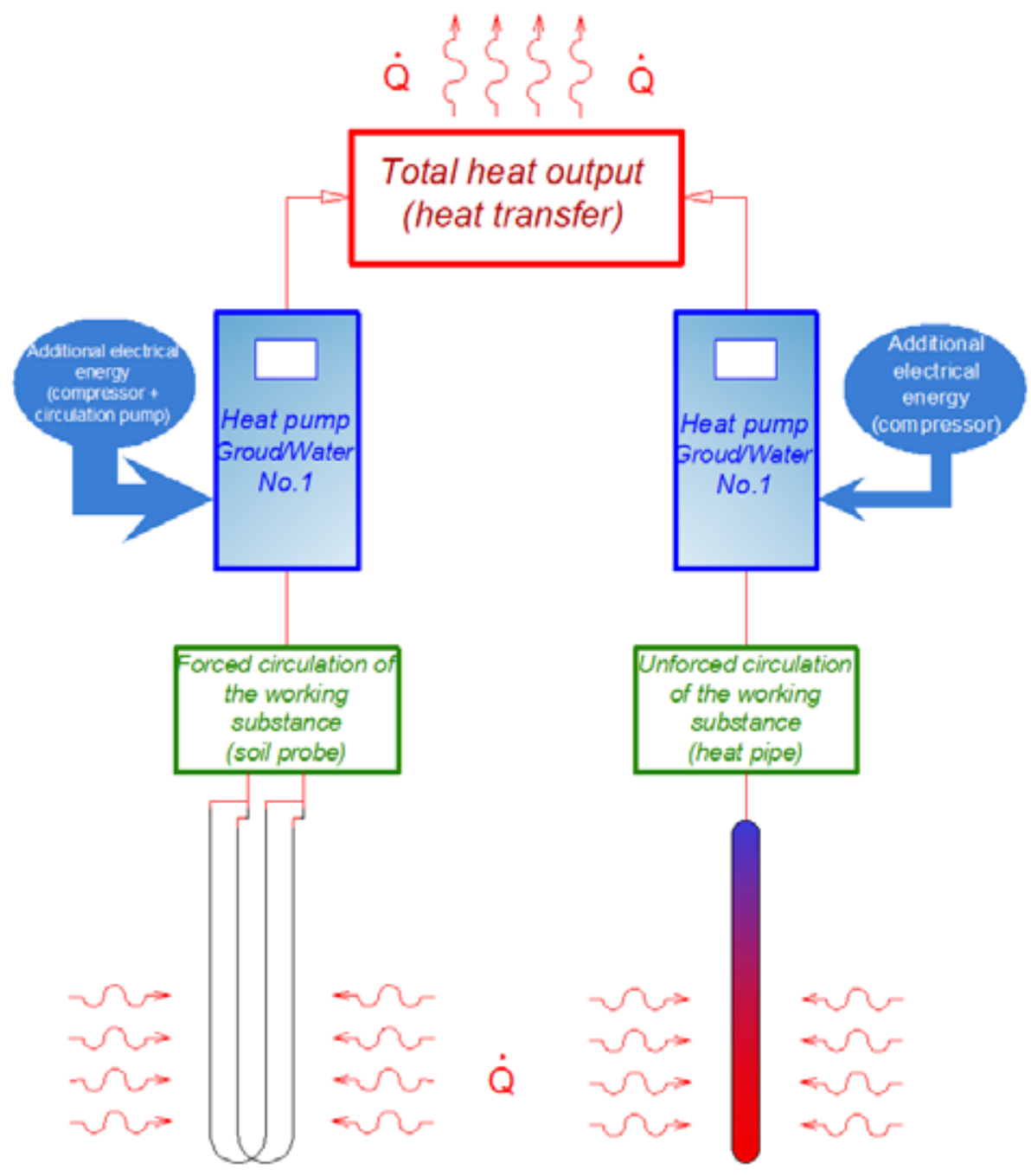

Fig. 1. Scheme for obtaining low-power heat 


\section{MEASUREMENT OF GROUND/WATER HEAT PUMP (HP) WITH FORCED CIRCULATION MEDIUM ON PRIMARY SIDE}

During the first two days only a circulation pump was in operation. Temperatures in the borehole slowly stabilized as temperature of the working substance. Temperature range of substances has stabilized at a value between $16.5^{\circ} \mathrm{C}$ to $17^{\circ} \mathrm{C}$. Temperatures at different depths of the well stabilized at values of: $11.7^{\circ} \mathrm{C}$ in 150 meters depth, $10.8^{\circ} \mathrm{C}$ at 100 and 40 meters deep and $5.3^{\circ} \mathrm{C}$ at five meters.

In the middle of the third day the heat pump started and its onset can be observed for changes in temperature. After a full-on heat pump performance, we have seen increased short-term performance of heat pumps as a result of higher initial potential of accumulated heat of the earth. Over time, the pump performance measurement has stabilized at a constant value of about $8 \mathrm{~kW}$, as indicated by the manufacturer. Temperatures at all depths gradually decreased and as a reduction potential of water temperature on secondary circuit was recorded. Due to low ambient temperature overnight to reduce the temperature of heating water returns to the secondary circuit HP. There were even more marked hypothermia of the working substance at the inlet and the outlet of the primary circuit of the heat pump and a slight increase in heat output obtained from the ground. Improves performance on the primary side just cause for the low temperature of the heat pump condenser (due to low night temperatures dropped and the temperature in the heated room and, thus to an increase in heat loss of the building). The refrigerant in the condenser is cooled to a lower temperature than usual, which resulted in an increase in heat flow evaporation of refrigerant in evaporator heat pump.

On the other days there are significant variations in temperature during the days. These fluctuations cause changes in temperatures of working substance in the primary and secondary side. In the last phase of measurements there was a significant warming weather which resulted in a slight stabilization of working substance of primary circuit and rise of working substance secondary circuit HP. During the measurement there was a slight descent working temperatures of substances on the primary and secondary circuits. This was caused by pumping heat from the ground and reducing potential temperature in the immediate vicinity of borehole. On subsequent days, the low-potential heat flow stabilized at a constant value or value with minimum decrease output.

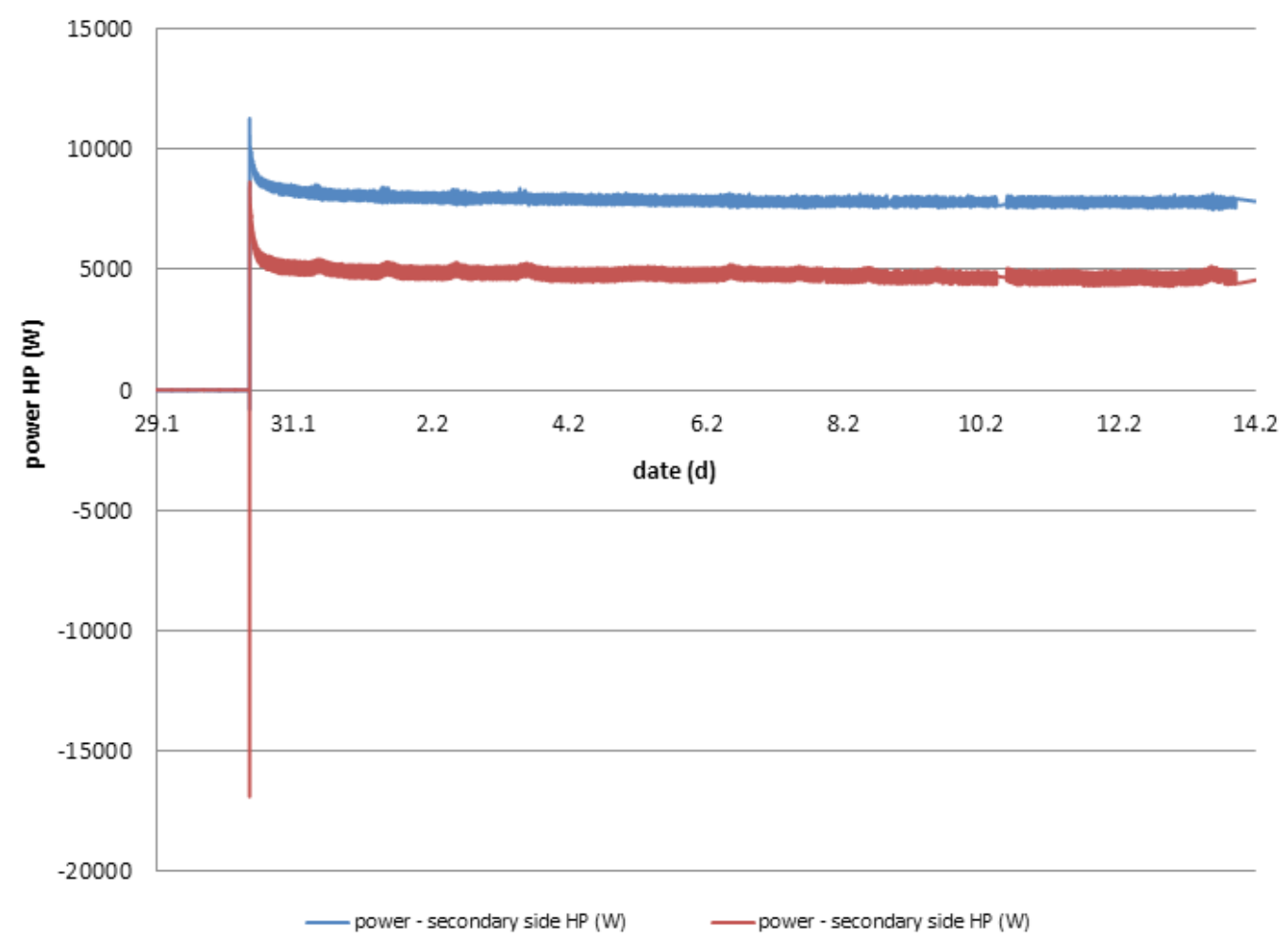

Fig. 2. Measuring performance of the heat pump 


\section{MEASUREMENT OF GROUND/WATER HEAT PUMP (HP) WITH HEAT PIPE ON PRIMARY SIDE}

The difference between the output obtained by a classical method of a forced circulation of the working substance and the one obtained by the heat pipe was considerable (Tab. 1).

Table 1. Measurement of heat output from a deep bore hole

\begin{tabular}{|l|c|c|}
\hline & $\begin{array}{c}\text { Forced circulation of the heat } \\
\text { transfer medium - bore hole }\end{array}$ & $\begin{array}{c}\text { Heat pipe - } \\
\text { measurment }\end{array}$ \\
\hline Max. measured power* & $7922 \mathrm{~W}$ & $3200 \mathrm{~W}$ \\
\hline Min. measured power* & $4950 \mathrm{~W}$ & $1550 \mathrm{~W}$ \\
\hline Average power* & $4980 \mathrm{~W}$ & $1900 \mathrm{~W}$ \\
\hline
\end{tabular}

* measured power on the heat pump primary circuit

It is obvious that the heat pipe did not continuously work with the designed heat transfer. This fact can be attributed to more factors having influence on the correct operation of the heat pipe. One problem was removed at the introductory measurement of the heat pipe and the output considerably increased and the heat pipe began working.

\section{CONCLUSION}

In a real experiment, $\mathrm{NH}_{3}$ was used as a working substance because of a lower operating pressure in the heat pipe. The measured performance characteristics for both methods were significantly different. Using a heat pipe, the heat gain was much faster than that of the standard probe. This is due to the immediate phase conversion of $\mathrm{NH}_{3}$ into the heat pipe and hence faster heat transfer. Later performance decreased and overall measured gains were lower than with a standard probe. This was due to the incorrect design of heat exchanger on condensing side of the heat pipe.

The measurement, however, has shown that heat pipes are an effective solution for the extraction of low Earth's heat. If the right design is to achieve a more efficient heat transfer and circulation of the nonfueled working substance. It is important to consider the choice of the substance from environmental, safety and heat transfer properties.

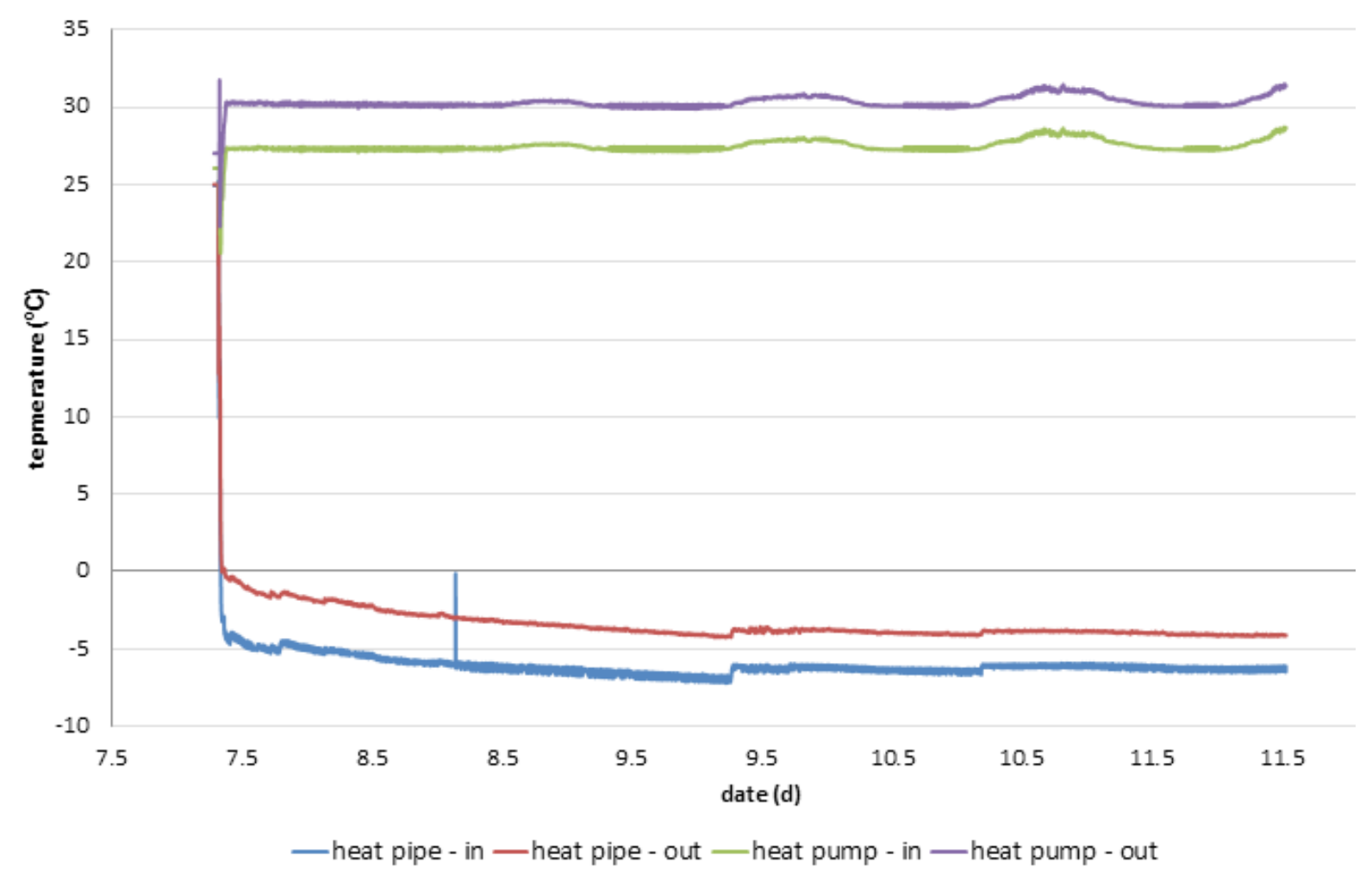

Fig. 3. Measuring temperatures in priamry and secondary sides of heat pumpwith $\mathrm{NH}_{3}$ heat pipe 


\section{REFERENCES}

[1] Nemec P., Výskum kapilárnych tepelných trubic pre prevádzkové teploty od -30 do $+50^{\circ} \mathrm{C}$. Zilina, Diploma work under supervision of: Milan Malcho, Žilinská univerzita v Žiline, Žilina 2010.

[2] Lenhard R., Numerical simulation device for the transport of geothermal heat with forced circulation of media. Kuching - Sarawak - Malaysia: Proc. of Fourth Global Conference on PCO 2010, 2010.

[3] Lenhard R., Jandačka J., Jakubsky M., Zariadenia na simuláciu transformácie nízkopotenciálneho geotermálneho tepla na teplo vhodné pre vykurovanie. Žilina 2010.

[4] Čaja A., Nemec P., Malcho M., The dependence of quantum and filling type to heat transport of gravity heat pipe. Liberec: Proc of Conf. Experimental fluid mechanics 2010, 2010.

[5] Jakubsky M., Lenhard R., Simulácia geotermálnych procesov: zariadenie na využitie nízko potenciálneho geotermálneho tepla bez núteného obehu tepelného nosiča v hlbokom vrte. „PRO-ENERGY magazín“ 2010, 4, pp. 56-58, ISSN 1802-4599.

[6] Lenhard R., Jakubsky M., Nemec P., Device for simulation of transfer geothermal heat with forced and without forced circulation of heat carrier. Kuching, Malaysia. Power control and optimization: proc. of fourth global conference. 2010, ISBN 978-983-44483-32.

[7] Lenhard R., Malcho M., Numerical simulation device for the transport of geothermal heat with forced circulation of media. „Mathematical and Computer Modelling“, 2013, 57, 1-2, pp. 111-125.

\section{Acknowledgement}

This publication is the result of the project implementation: Device for the use of low-potential geotermal heat without forced circulation of the heat carier in deep boreholes, ITMS 26220220057 supported by the Operational Programme Research and development funded by the ERDF. 